\title{
A trial of the effects of soya-bean flour and soya-bean saponins on plasma lipids, faecal bile acids and neutral sterols in hypercholesterolaemic men
}

\author{
BY G. D. CALVERT AND LESLEY BLIGHT \\ Department of Clinical Biochemistry, Flinders Medical Centre, Bedford Park, \\ South Australia 5042, Australia \\ AND R. J. ILLMAN, D. L. TOPPING AND J. D. POTTER \\ CSIRO Division of Human Nutrition, Kintore Avenue, Adelaide, South Australia 5000, \\ Australia
}

(Received 26 August 1980-Accepted 4 November 1980)

\begin{abstract}
1. The hypothesis that soya-bean saponins, by binding bile salts in the gastrointestinal lumen, are responsible for some of the plasma-cholesterol-lowering effect of soya-bean preparations, was tested. In a double-blind crossover study $50 \mathrm{~g}$ soya-bean flour $/ \mathrm{d}$, containing either 22 or $4 \mathrm{~g}$ saponins $/ \mathrm{kg}$ (adjusted by ethanol extraction) was incorporated in biscuits as a substitute for biscuits or bread into the diet of ten outpatient hypercholesterolaemic men over two consecutive 4-week study periods. The diet was monitored to ensure constancy, saponin-rich foods excluded, faeces collected for bile acid and neutral sterol analysis, and blood taken for plasma lipoprotein lipid analysis.

2. Neither diet had any effect on cholesterol in any plasma lipoprotein fraction, on fasting plasma triglyceride, or on faecal bile acids and neutral sterols.

3. These results suggested that soya-bean saponins are not responsible for the hypocholesterolaemic effect of soya-bean products.
\end{abstract}

Several studies have shown that soya-bean products, in particular textured vegetable protein, may lower plasma cholesterol. Hodges et al. (1967) showed that complete substitution of animal protein by soya-bean textured vegetable protein in the diet of male prison inmates for 4 weeks resulted in a fall of approximately $40 \%$ in serum cholesterol. More recently Sirtori et al. (1977) obtained a fall of about $21 \%$ in plasma cholesterol in hypercholesterolaemic patients by the substitution of textured vegetable (soya-bean) protein for dietary animal protein. In a similar experiment Carroll et al. (1978) observed a fall of approximately $5 \%$ in plasma cholesterol in free-living normocholesterolaemic young women.

Although there is evidence that some of these changes are at least partly the result of substitution of plant for animal protein (Huff et al. 1977) it is plain that other dietary constituents may modify the hypocholesterolaemic response (Kritchevsky et al. 1977). It has been suggested that soya-bean saponins are partly responsible for the observed lowering of plasma cholesterol (Potter et al. 1979). Saponins are surface active substances of plant origin, which are poorly absorbed from the gastrointestinal tract (Basu \& Rastogi, 1967; Birk, 1969). Some saponins have been shown to increase faecal steroids in man and in experimental animals, and in some instances to lower plasma cholesterol (Griminger \& Fisher, 1958; Newman et al. 1958; Shibata, 1961; Malinow, McLaughlin, Kohler et al. 1977; Malinow, McLaughlin, Papworth et al. 1977; Malinow, 1979; Sautier et al. 1979; Topping, Storer $e t$ al. 1980), probably as a result of binding bile acids (Oakenfull \& Fenwick, 1978). In rats faecal bile acid excretion, especially primary bile acid excretion, and neutral sterol excretion increased with dietary soya-bean flour rich in saponins (as compared with saponin-depleted soya-bean flour; the same soya-bean flour preparations were used as in 
the present study) and soya-bean flour, irrespective of saponin content, lowered plasma cholesterol (Topping, Trimble et al. 1980).

It seemed appropriate to test whether the saponins of soya-bean flour had any potential therapeutic effect in the diet of a free-living population most at risk from coronary heart disease, i.e. hypercholesterolaemic men. Therefore, we performed a double-blind crossover study in which biscuits containing either whole soya-bean flour $(\mathbf{S}+)$ or similar soya-bean flour from which saponins had been largely extracted $(\mathrm{S}-)$ were incorporated into the diets of subjects living at home.

\section{EXPERIMENTAL}

Study design

Commercial defatted soya-bean flour was extracted with ethanol-water $(80: 100, \mathrm{v} / \mathrm{v})$ for $24 \mathrm{~h}$ at room temperature, with frequent stirring. The extraction was repeated eight times. Before extraction the dry flour $(\mathrm{S}+$ ) contained $22 \mathrm{~g}$ saponins $/ \mathrm{kg}$ and after extraction the $\mathrm{S}$ - flour contained $4 \mathrm{~g}$ saponin $/ \mathrm{kg}$. Biscuits were made either from the $\mathrm{S}+$ or the $\mathrm{S}-$ flour.

A double-blind crossover design was used to examine the effect of the saponin content of dietary soya-bean flour on plasma lipids and faecal neutral sterols and bile acids. Subjects were randomly assigned to receive either $S+$ or $S$ - biscuits for 4 weeks and for the next 4 weeks the alternate type of biscuit. Each subject was given $50 \mathrm{~g}$ soya-bean flour (in biscuits) to eat daily. Equal amounts of biscuit were eaten three times daily with each major meal. Consumption was monitored by counting surplus biscuits weekly. Five subjects had the $\mathrm{S}+$ biscuit first, and five subjects the $\mathrm{S}$ - biscuits. The study was approved by the Medical Centre Ethics Committee.

\section{Subjects}

All ten participants were non-smoking men who had attended a cardiovascular risk screening clinic within the last few months, when their plasma cholesterol concentrations were $6.5 \mathrm{mmol} / 1$ or more. All were asymptomatic, were not receiving any medication, had no history of heart, metabolic or gastrointestinal disease, and had no history of recent serious illness; details are given in Table 1. Fully informed consent was gained.

Subjects lived at home. Usual diets were ascertained, then diet composition was maintained as constantly as possible throughout the study by a dietitian visiting the patient's home. The soya-bean flour biscuits were substituted for biscuits or bread. Efforts were made to maintain dietary energy content, exercise habits, and weight as constant as possible. Diets, monitored with weekly diet histories, were analysed with standard food tables (Paul \& Southgate, 1978). Saponin-rich foods were avoided. Small amounts of alcohol were allowed. Subjects were weighed weekly.

Table 1. Subjects enrolled in the study

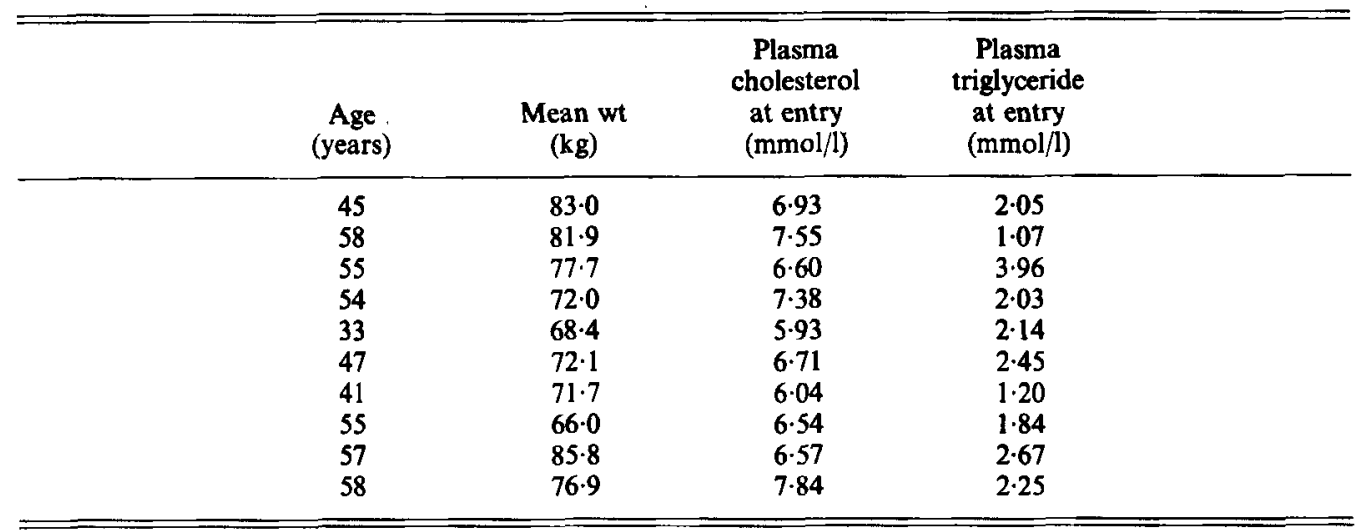


For $3 \mathrm{~d}$ at the end of the second, third and fourth week of each study period all faeces were collected and promptly frozen at $-20^{\circ}$. Faecal bile acids and neutral sterols were determined by gas-liquid chromatography (Topping et al. 1978). At entry, and once every week of the study, fasting plasma lipids and lipoproteins were measured using the Lipid Research Clinics protocol (Lipid Research Clinics Program, 1974) with a modification for high-density-lipoprotein cholesterol measurement (Warnick \& Albers, 1978), in a laboratory standardized for precision and accuracy by the WHO Collaborating Centre for Reference and Research into Blood Lipids, Centre for Disease Control, Atlanta, Georgia, USA. After lipoprotein separation samples were stored at $-70^{\circ}$ and analysed in a single batch at the end of the study to minimize analytical variation. All statistical comparisons were made using the paired $t$ test.

\section{RESULTS}

Individual diets differed, though each participant attempted and was encouraged to maintain a constant dietary intake (i.e. a nutritionally-adequate diet which had been determined to be representative of their usual diet) throughout the study. Of the protein energy $64-83 \%$ (mean $\pm \mathrm{SE} 74.0 \pm 1.9 \%$ ) was of animal origin. The mean value for polyunsaturated :saturated fats was $0 \cdot 65$ (range $0 \cdot 20-1 \cdot 18)$. Cholesterol intake ranged from 74 to $490 \mathrm{mg} / \mathrm{d}$ (all subjects had been advised at the screening clinic to limit dietary cholesterol). There were no over-all differences in energy intake or the major dietary constituents (fat, carbohydrate, animal protein, plant protein, cholesterol) between the S+ and $\mathbf{S}-$ periods. There was no difference between the mean body-weights in the $\mathbf{S}+$ and $\mathbf{S}-$ periods. All subjects claimed to have eaten the prescribed biscuits every day (usually three times daily), and a count of residual biscuits supported this.

There was no significant change in plasma cholesterol, triglyceride, nor in very-lowdensity-, low-density- or high-density-lipoprotein cholesterol in the group, neither at the end of the study compared with entry to the study, nor in the last 3 weeks of the second dietary period compared with the first, nor in the last 3 weeks of the $S+$ period compared with that of the $S$ - period (Table 2).

There was no significant change in the faecal excretion of neutral sterols nor of bile acids in the $\mathrm{S}+$ period compared with the $\mathrm{S}$ - period, either when expressed as mg excreted per $\mathrm{g}$ faeces (Table 3 ) or as $\mathrm{mg} / \mathrm{d}$.

Table 2. Plasma lipids in the ten hypercholesterolaemic men ( $m$ mol/l)

(Mean values with their standard errors for three measurements 2, 3 and 4 weeks after diet began, for each subject)

\begin{tabular}{|c|c|c|c|c|}
\hline & \multicolumn{2}{|c|}{$\begin{array}{l}\text { Saponin-depleted } \\
\text { (S-) } \\
\text { soya-bean } \\
\text { flour in } \\
\text { diet }\end{array}$} & \multicolumn{2}{|c|}{$\begin{array}{l}\text { Unextracted } \\
(\mathbf{S}+) \\
\text { soya-bean } \\
\text { flour in } \\
\text { diet }\end{array}$} \\
\hline & Mean & $\mathbf{S E}$ & Mean & $\mathbf{S E}$ \\
\hline $\begin{array}{l}\text { Plasma cholesterol } \\
\text { VLDL cholesterol } \\
\text { LDL cholesterol } \\
\text { HDL cholesterol } \\
\text { Plasma triglyceride }\end{array}$ & $\begin{array}{l}6.92 \\
1.08 \\
4.68 \\
1 \cdot 10 \\
2.04\end{array}$ & $\begin{array}{l}0.09 \\
0.08 \\
0.12 \\
0.04 \\
0 \cdot 14\end{array}$ & $\begin{array}{l}6.87 \\
1.07 \\
4.63 \\
1 \cdot 11 \\
2.11\end{array}$ & $\begin{array}{l}0.07 \\
0 \cdot 10 \\
0 \cdot 10 \\
0.04 \\
0.16\end{array}$ \\
\hline
\end{tabular}


Table 3. Faecal neutral sterols and bile acids ( $\mathrm{mg} / \mathrm{g}$ dry weight) in the ten hypercholesterolaemic men

(Mean values for three $3 \mathrm{~d}$ collections from each subject)

\begin{tabular}{lccccc}
\hline & $\begin{array}{c}\text { Saponin-depleted } \\
\text { (S-) } \\
\text { soya-bean } \\
\text { flour in } \\
\text { diet }\end{array}$ & $\begin{array}{c}\text { Unextracted } \\
\text { (S+) } \\
\text { soya-bean } \\
\text { flour in } \\
\text { diet }\end{array}$ \\
\cline { 2 - 5 } & Mean & SE & Mean & SE \\
Cholesterol & 3.36 & 0.68 & 3.56 & 0.52 \\
Coprostanol & 14.67 & 1.26 & 14.46 & 1.20 \\
Coprostanone & 0.64 & 0.13 & 0.60 & 0.11 \\
Total faecal neutral sterols & 18.38 & 1.06 & 18.81 & 1.01 \\
Cholic acid & 0.47 & 0.03 & 0.59 & 0.04 \\
Chenodeoxycholic acid & 1.04 & 0.11 & 1.17 & 0.10 \\
Total primary acids & 1.55 & 0.13 & 1.75 & 0.12 \\
Deoxycholic acid & 2.26 & 0.19 & 2.60 & 0.27 \\
Lithocholic acid & 1.72 & 0.16 & 1.75 & 0.19 \\
Ursodeoxycholic acid & 0.53 & 0.14 & 0.54 & 0.15 \\
Total secondary bile acids & 4.69 & 0.40 & 4.53 & 0.48 \\
Total bile acids & 6.24 & 0.48 & 6.50 & 0.56 \\
\hline
\end{tabular}

No significant difference by paired $t$ test.

\section{DISCUSSION}

In our outpatient population of hypercholesterolaemic middle-aged men, neither $\mathbf{S}+$ nor $S$ - flour had any effect on plasma lipids or faecal bile acids or neutral sterols when included in a mixed Australian diet. The hypothesis being tested, that soya-bean saponins, by binding bile salts in the gastrointestinal lumen, are responsible for the hypocholesterolaemic effect of soya-bean preparations, has not been supported.

In a recent similar study (Potter et al. 1980) on normocholesterolaemic subjects with very close dietary monitoring, inclusion of $\mathbf{S}+$ flour in the diet resulted in increased primary bile acid excretion but also no significant change in plasma cholesterol (when compared with the $S$ - flour).

Major effects with soya-bean substitution have been observed only in closely-supervised populations with other major dietary manipulations (Hodges et al. 1967; Sirtori et al. 1977). In less closely supervised populations, without major dietary changes, either minor (Carroll et al. 1978; Sirtori et al. 1979) or no effects (Munoz et al. 1979) have been noted. For example, Sirtori et al. (1979) reported that the soya-bean-protein diet had a much smaller hypocholesterolaemic effect in outpatients than in subjects in a metabolic ward, and Munoz et al. (1979) found no effect on plasma lipids of soya-bean textured vegetable protein in men eating an otherwise average American diet.

Other saponins may have different effects on cholesterol metabolism. For instance those probably from Saponaria officinalis partially reverse the hypercholesterolaemia caused by a high-cholesterol diet in rats, and increase faecal excretion of bile acids and neutral sterols (Oakenfull et al. 1979). Alfalfa (lucerne) saponins in the diet prevent diet-induced hypercholesterolaemia in monkeys (Malinow, McLaughlin, Kohler et al. 1977). Saponins from different plant species differ in structure (Basu \& Rastogi, 1967; Birk, 1969), and may differ in their ability to bind sterols or in their biological effect when added to the diet. 
This work was supported by grants from the National Heart Foundation of Australia and the National Health and Medical Research Council.

The authors thank DrD. G. Oakenfull and associated staff of the CSIRO, Division of Food Research, New South Wales, for preparing the soya-bean flour, Mrs Nella Topping for preparing the biscuits, and Miss Julianne McKeough, dietitian, Miss Tiina Mannik and Miss Jenny Fewster for their expert help. Above all, they thank the subjects for their willing participation.

\section{REFERENCES}

Basu, N. \& Rastogi, R. P. (1967). Phytochemistry 6, 1249.

Birk, Y. (1969). In Toxic Constituents of Plant Foodstuffs [I. E. Liener, editor]. New York: Academic Press.

Carroll, K. K., Giovannetti, P. M., Huff, M. W., Moase, O., Roberts, D. C. K. \& Wolfe, B. M. (1978). Am. J. clin. Nutr. 31, 1312.

Griminger, P. \& Fisher, H. (1958). Proc. Soc. exp. Biol. 99, 424.

Hodges, R. E., Krehl, W. A., Stone, D. B. \& Lopez, A. (1967). Am. J. clin. Nutr. $20,198$.

Huff, M. W., Hamilton, R. M. G. \& Carroll, K. K. (1977). Atherosclerosis 28, 187.

Kritchevsky, D., Tepper, S. A., Williams, D. E. \& Story, J. A. (1977). Atherosclerosis 26, 397.

Lipid Research Clinics Program (1974). Manual of Laboratory Operations, Lipid and Lipoprotein Analysis. DHEW Publication No. (NIH) 75-628.

Malinow, M. R. (1979). Vth Int. Symp. Atherosclerosis, Houston, Texas. (Abstr. no. 302).

Malinow, M. R., McLaughlin, P., Kohler, G. O. \& Livingston, A. L. (1977). Steroids 29, 105.

Malinow, M. R., Mclaughlin, P., Papworth, L., Stafford, C., Kohler, G. O., Livingston, A. L. \& Cheeke, P. R. (1977). Am. J. clin. Nutr. 30, 2061.

Munoz, J. M., Sandstead, H. H., Jacob, R. A., Logan, G. M., Reck, S. J., Klevay, L. M. \& Shuey, W. C. (1979). Am. J. clin. Nutr. 32, 580.

Newman, H. A. I., Kummerow, F. A. \& Scott, H. M. (1958). Poult. Sci. 37, 42.

Oakenfull, D. G. \& Fenwick, D. E. (1978). Br. J. Nutr. 40, 299.

Oakenfull, D. G., Fenwick, D. E., Hood, R. L., Topping, D. L., Illman, R. J. \& Storer, G. B. (1979). Br. J. Nutr. 42, 209.

Paul, A. A. \& Southgate, D. A. T. (1978). McCance and Widdowson's The Composition of Foods. London: H.M. Stationery Office.

Potter, J. D., Illman, R. J., Calvert, G. D., Oakenfull, D. G. \& Topping, D. L. (1980). Nutr. Rep. int. (In the Press).

Potter, J. D., Topping, D. L. \& Oakenfull, D. G. (1979). Lancet i, 223.

Sautier, C., Doucet, C., Flament, C. \& Lemonnier, D. (1979). Atherosclerosis 34, 233.

Shibata, N. (1961). Med. J. Osaka Univ. 12, 297.

Sirtori, C. R., Agradi, E., Conti, F., Mantero, O. \& Gatti, E. (1977). Lancet i, 275.

Sirtori, C. R., Gatti, E., Mantero, O., Conti, F., Agradi, E., Tremoli, E., Sirtori, M., Fraterrigo, L., Tavazzi, L. \& Kritchevsky, D. (1979). Am. J. clin. Nutr. 32, 1645.

Topping, D. L., Illman, R. J., Dreosti, I. E., Trimble, R. P. \& Record, I. R. (1978). Nutr. Rep. int. $18,631$.

Topping, D. L., Storer, G. B., Calvert, G. D., Illman, R. J., Oakenfull, D. G. \& Weller, R. A. (1980). Am. J. clin. Nutr. 33, 783.

Topping, D. L., Trimble, R. P., Illman, R. J., Potter, J. D. \& Oakenfull, D. G. (1980). Nutr. Rep. int. (In the Press.)

Warnick, G. R. \& Albers, J. J. (1978). J. Lipid Res. 19, 65. 